\title{
Erratum to: Practical impacts of genomic data "cleaning" on biological discovery using surrogate variable analysis
}

Andrew E. Jaffe ${ }^{1,2}$, Thomas Hyde ${ }^{1,3,4}$, Joel Kleinman ${ }^{1,3}$, Daniel R. Weinberger ${ }^{1,3,4,6}$, Joshua G. Chenoweth', Ronald D. McKay ${ }^{1}$, Jeffrey T. Leek ${ }^{2}$ and Carlo Colantuoni ${ }^{1,3,5^{*}}$

After publication of the original article [1] it was brought to our attention that author Daniel R. Weinberger was incorrectly included as Daniel R. Weinbergern. The correct spelling of the name is included in the author list of this erratum.

\begin{abstract}
Author details
'Lieber Institute for Brain Development, 855 N Wolfe St, Ste 300, Baltimore, MD 21205, USA. ²Department of Biostatistics, Johns Hopkins Bloomberg School of Public Health, 615 N Wolfe St, Baltimore, MD 21205, USA. ${ }^{3}$ Department of Neurology, Johns Hopkins School of Medicine, Baltimore, MD 21205, USA. ${ }^{4}$ Department of Psychiatry, Johns Hopkins School of Medicine, Baltimor, MD 21205, USA. ${ }^{5}$ Department of Neuroscience, Johns Hopkins School of Medicine, Baltimore, Maryland 21205, USA.

${ }^{6}$ McKusick-Nathans Institute of Genetic Medicine, Johns Hopkins School of Medicine, Baltimore, Maryland 21205, USA.
\end{abstract}

Published online: 10 August 2016

\section{Reference}

1. Jaffe et al.: Practical impacts of genomic data "cleaning" on biological discovery using surrogate variable analysis. BMC Bioinformatics (2015) 16:372 DOI 10.1186/s12859-015-0808-5

\footnotetext{
* Correspondence: carlo.colantuoni@libd.org

'Lieber Institute for Brain Development, 855 N Wolfe St, Ste 300, Baltimore, MD 21205, USA

${ }^{3}$ Department of Neurology, Johns Hopkins School of Medicine, Baltimore, MD 21205, USA

Full list of author information is available at the end of the article
}

Submit your next manuscript to BioMed Central and we will help you at every step:

- We accept pre-submission inquiries

- Our selector tool helps you to find the most relevant journal

- We provide round the clock customer support

- Convenient online submission

- Thorough peer review

- Inclusion in PubMed and all major indexing services

- Maximum visibility for your research

Submit your manuscript at www.biomedcentral.com/submit (c) 2016 The Author(s). Open Access This article is distributed under the terms of the Creative Commons Attribution 4.0 International License (http://creativecommons.org/licenses/by/4.0/), which permits unrestricted use, distribution, and reproduction in any medium, provided you give appropriate credit to the original author(s) and the source, provide a link to the Creative Commons license, and indicate if changes were made. The Creative Commons Public Domain Dedication waiver (http://creativecommons.org/publicdomain/zero/1.0/) applies to the data made available in this article, unless otherwise stated. 